\title{
Associations between agronomic and bread-making quality traits in wheat: location and crop-year effects
}

\section{Associações entre caracteres agronômicos e de qualidade industrial em trigo: efeito de anos e locais de cultivo}

\section{Elesandro BORNHOFEN'; Leomar Guilherme WOYANN²; Antonio Henrique BOZl; Matheus Giovani STOCO${ }^{4}$; Volmir Sérgio MARCHIORO5; Giovani BENIN ${ }^{6}$}

\footnotetext{
${ }^{1}$ Mestre. Universidade Tecnológica Federal do Paraná- UTFPR. Câmpus Pato Branco. Via do Conhecimento, km 1. CEP 85503-390 - Pato Branco - PR - Brazil. elesandro.bornhofen@gmail.com

${ }^{2}$ Mestre. Universidade Tecnológica Federal do Paraná- UTFPR. Câmpus Pato Branco. Via do Conhecimento, km 1. CEP 85503-390 - Pato Branco - PR - Brazil. leowoyann@gmail.com

${ }^{3}$ Graduando. Universidade Tecnológica Federal do Paraná- UTFPR. Câmpus Pato Branco. Via do Conhecimento, km 1. CEP 85503-390 - Pato Branco - PR - Brazil. jouxa@hotmail.com

${ }^{4}$ Graduando. Universidade Tecnológica Federal do Paraná- UTFPR. Câmpus Pato Branco. Via do Conhecimento, km 1. CEP 85503-390 - Pato Branco - PR - Brazil. mateus_kst01@hotmail.com

${ }^{5}$ Doutor. Cooperativa Central de Pesquisa Agrícola, Caixa Postal 301, CEP $85813-450$ Cascavel, PR. volmir@marchioro.eng.br

${ }^{6}$ Autor para correspondência: benin@utfpr.edu.br, Doutor. Universidade Tecnológica Federal do Paraná- UTFPR. Câmpus Pato Branco. Via do Conhecimento, km 1. CEP 85503-390 - Pato Branco - PR - Brazil
}

Recebido em: 03-02-2017; Aceito em: 26-09-2017

\begin{abstract}
The present study aimed to evaluate the associations between agronomic and bread-making quality traits in wheat under different growing environments. Nineteen Brazilian wheat cultivars were evaluated at six locations (Cascavel-PR, Castro-PR, Guarapuava-PR, Palotina-PR, Abelardo Luz-SC, and Não-Me-Toque-RS) during five years (2007 to 2011). The direction and magnitude of the associations between agronomic and bread-making quality traits were strongly dependent on the test location and year of evaluation. This study discusses the implications of choosing test locations on bread-making quality traits and for breeding purposes, with emphasis on indirect selection.
\end{abstract}

Additional keywords: flour color; gluten strength; Triticum aestivum L.; wheat breeding.

\section{Resumo}

Este estudo teve por objetivo avaliar a associação entre caracteres agronômicos e de qualidade de panificação de trigo, em diferentes ambientes de cultivo. Dezenove cultivares foram avaliadas em seis locais de cultivo (Cascavel-PR, Castro-PR, Guarapuava-PR, Palotina-PR, Abelardo Luz-SC e Não-Me-Toque-RS), durante os anos de 2007 a 2011. O sentido e a magnitude das associações entre os caracteres agronômicos e os parâmetros indicativos da qualidade de panificação foram fortemente dependentes do local de teste e do ano de avaliação. As implicações da escolha do local de cultivo sobre a qualidade industrial e o melhoramento da cultura, com ênfase à seleção indireta, são discutidas.

Palavras-chave adicionais: cor de farinha; força de glúten; melhoramento de trigo; Triticum aestivum L.

\section{Introduction}

The bread-making quality of wheat flour is complex and mainly determined by protein content and its qualitative and quantitative variations, which depend on genotype $(G)$, environment $(E)$, and their interaction (G x E) (Taghouti et al., 2010; Tayyar, 2010). The E effect frequently implies changes in traits associations (Guarienti et al., 2003) leading to the necessity for studies aiming to identify associated traits in specific environmental conditions. The identification of specific associations has crucial importance in plant breeding once it can support the selection process of superior genotypes, impacting the genetic gain in the breeding program.
The variation of bread-making quality traits across environments is an element that difficulties the end-use of wheat flour. For a given bread-making quality requirement, an adequate genotypic selection is crucial, and the location appears to have secondary importance (Souza et al., 2004). However, several studies have reported that a substantial part of the variation for quality traits is explained by the effects of location, year, and their interactions with genotype (Lukow et al., 2013; Surma et al., 2012; Bilgin et al., 2016). These sources of variation have more or less impact depending on the trait under evaluation. In addition, the breeding process changes the performance of agronomic and quality traits through the years (del 
Pozo et al., 2014). Hence, these information supports the necessity for frequent studies about the association pattern of important traits for wheat breeding.

Numerous studies have detailed correlations between agronomic and bread-making quality traits of wheat (Zanetti et al., 2001; Tayyar, 2010; Mohammed et al., 2012; Surma et al., 2012) however, with a restricted quantity of environments. Thus, the aim of this study was to evaluate the associations between agronomic and bread-making quality traits of Brazilian spring wheat evaluated in multi-environment conditions (5 years and 6 locations).

\section{Material and methods}

The dataset used in this study is part of the Value for Cultivation and Use (VCU) trials network carried out by the wheat breeding program of the Central Cooperative of Agricultural Research (COODETEC). Nineteen wheat cultivars (CD 104, CD 105, CD 108, CD 110, CD 111, CD 113, CD 114, CD 115, CD 117, CD 119, CD 120, CD 121, CD 123, CD 124, CD 1552, CD 150, CD 154, IPR 85, and Ônix) were evaluated at six locations (Abelardo Luz - SC, Cascavel - PR, Castro - PR, Guarapuava - PR, NãoMe-Toque - RS, and Palotina - PR) during five crop seasons (2007 to 2011).

Each experiment was carried out using a randomized complete block design with three replicates. The plots consisted of six $5 \mathrm{~m}$ rows spaced $0.20 \mathrm{~m}$ apart, totaling $6.0 \mathrm{~m}^{2}$. The crop management was carried out in accordance with the wheat recommendations published annually (RCBPTT, 2008). The following agronomic traits were measured: grain yield (GY, $\mathrm{kg} \mathrm{ha}^{-1}$ ) and hectoliter weight (HW; kg $\left.100 \mathrm{~L}^{-1}\right)$, corrected to $13 \%$ moisture. In addition, the following bread-making quality traits were evaluated: falling number (FN; seconds), extensibility ( $\mathrm{L} ; \mathrm{mm})$, tenacity $(P ; \mathrm{mm})$, tenacity/extensibility ratio $(\mathrm{P} / \mathrm{L})$, gluten strength $\left(\mathrm{W} ; \times 10^{-4} \mathrm{~J}\right)$, and flour color parameters represented by the scales $a^{*}, b^{*}$ and $L^{*}$ (CIE - Commission Internationale de l'Éclairage, International Commission on Illumination). The qualitative analysis of the flour samples was performed according to standard methods (AACCI, 2010).

The associations between traits were evaluated through Pearson's correlation coefficients using the Genes software (Cruz, 2013). The graphics were elaborated using the software Sigmaplot v.11 and only the significant correlations $(p<0.05)$ and those relevant for breeding purposes were shown.

\section{Results and discussion}

Figure 1 shows more pronounced variations in the magnitude of the correlations between locations (Figure 1c, d) compared to years (Figure 1a, b). Variations in the magnitude and direction of the associations between traits are due to the effect of environment, characterized by the variability of years and crop loca- tions (Bakker et al., 2005). Therefore, multi-environment trials have significant importance and the breeder have to perform assessments combining crop locations and years in order to reduce the effect of single-environment atypical conditions.

The magnitude and significance of the correlation "GY x HW" was location and year-dependent (Figure 1b, d). The positive and high-magnitude association between "GY x HW" in Castro $(r=0.90 ; p<0.01)$ is the result of the high photothermal quotient $(P Q)$, frequently observed in high altitude regions (Silva et al., 2014). High PQ locations allow growth stages elongation and consequently higher grain filling and GY. In addition, there was a significant association between "GY x W" ( $r=0.60 ; p<0.01)$, "W x FN" $(r=0.40$; $p<0.01)$, and "HW $x$ FN" $(r=0.60 ; p<0.01)$ in Castro. Therefore, due to positive environmental stimuli, the selection of genotypes that combine high GY and bread-making quality traits, e.g. W, HW, and $\mathrm{FN}$, is facilitated in Castro. Trials carried out under excellent environmental conditions enables to maximize most of the desirable traits, including W. However, as the GY increases, $W$ does not follow in the same proportion. This implies the absence of significant association between GY and W for most locations and years.

Genotypic variations and environmental factors affect the color of wheat flour (Taghouti et al., 2010). Wheat flour with high brightness $\left(L^{*}>94\right)$ is preferred as they may be intended for the manufacture of several products and to make blends with low $L^{*}$ flour. The results show that $W$ was negatively correlated with $L^{*}$ in the average of years $(r=-0.42)$ and locations $(r=-0.23)$, although with more variability mainly for crop locations. In addition, $\mathrm{L}^{*}$ is inversely correlated with protein content and grain hardness (Souza et al., 2004; Lukow et al., 2013). The crop location variability regarding the magnitude and significance of the relationship between $W$ and $L^{*}$ indicates the possibility to obtain wheat flour with different level of brightness by choosing different crop regions, a fact also reported by Lukow et al. (2013).

Lutein is highly associated with the yellow color of the flour, expressed by color $b^{*}$ (Hung \& Hatcher, 2011). The presence of carotenoids also reduces $L^{*}$ values, which are determinants of flour color (Adom et al., 2003; Hung \& Hatcher, 2011). A positive correlation was found between $W$ and $b^{*}$ in the average of years $(r=0.48)$ and locations $(r=0.36)$. According to Lukow et al. (2013), crop locations with higher average temperatures maximize grain protein accumulation and explains most of the association between $\mathrm{W}$ and $\mathrm{b}^{*}$.

The correlation "P $\mathrm{x}$ W" was significant $(\mathrm{p}<0.01)$ in all years $(\bar{r}=0.75)$ and locations $(\bar{r}=0.76)$, in accordance with other studies (Zanetti et al., 2001; Tayyar, 2010). In general, wheat cultivars with high values of $W$ also have high values of $P$. Li et al. (2013) report that $W$ has a positive correlation with $P / L$ ratio, so that high bread-making quality cultivars (with high W) also have a $\mathrm{P} / \mathrm{L}$ ratio above 1 . In addition, the 
results show that $P / L$ has a positive correlation with color $b^{*}$, which also explains the low brightness of high W flour.

Gliadin and glutenin are the main glutenforming proteins (Peña et al., 2005). The glutenin is highly dependent on genotype and determines dough tenacity $(P)$, whereas gliadin (monomeric proteins) is sensitive to environmental variation and determine dough extensibility (L) (Peña et al., 2005). In W and
$\mathrm{P} / \mathrm{L}$, there is more influence of proteins of the glutenin group (Peña et al., 2005). In this sense, significant variations between locations and years, especially in relation to temperature, affect mainly $L$ (environmentdependent), with lower influence on $P$ (genotypedependent) (Li et al., 2013). For this reason, $\mathrm{W}$ and $\mathrm{L}$ do not vary together (absence of covariance), which possibly implies no association.

(a)


Amplitude ${ }^{1 /}$ Trait mean ${ }^{2}$

\begin{tabular}{|c|c|c|c|}
\hline HW: $60-84^{1} / 76.5^{2}{\mathrm{~kg} 100 \mathrm{~L}^{-1}}^{-1}$ & FN: $111-652 / 341 \mathrm{~s}$ & $W: 58-456 / 217 \times 10^{-4} \mathrm{~J}$ & Color $L^{*}: 79.8-95.7 / 92.4$ Color $b^{*}: 5.5-15.4 / 9.6$ \\
\hline
\end{tabular}

Figure 1 - Pearson's correlation coefficient between agronomic and bread-making quality traits obtained from Value for Cultivation and Use (VCU) trials conducted in five years and at six locations. HW: hectoliter weight, FN: falling number, W: gluten strength, P: tenacity, L: extensibility, P/L: tenacity/extensibility ratio, GY: grain yield. Subfigures "a" and "c" are the correlations between "HW x FN", "W x FN", "W x Color L", "W x Color b" and "P/L $x$ Color b" considering years (a) and crop locations (b). Likewise, subfigures " $b$ " and " $d$ " are the correlations for years and locations, respectively, between the traits "L x W", "GY x HW", "GY x W", "GY x Color a*", and "P x W". ${ }^{*},{ }^{* *}$ - indicate significant values at 5 and $1 \%$ error probability by t-test, respectively $(p \leq 0.05$ and $p \leq 0.01)$.

\section{Conclusions}

The existence of correlations between important agronomic traits in wheat is dependent on variations of years and, mainly, of crop locations, requiring the assessment and genotype selection in multi-environment. The observed associations demonstrate the difficulty to obtain high gluten strength, balanced $\mathrm{P} / \mathrm{L}$ ratio, high brightness flour, and high grain yield cultivars. The selection for high bread-making quality is associated with low flour brightness. The results of this study also indicate that it is possible to produce differentiated wheat flour by choosing the appropriate crop region (varying latitude and elevation), aiming to meet specific industry requirements. 


\section{Acknowledgements}

The authors thank the Coordination for the Improvement of Higher Education Personnel (CAPES) for the scholarship granted and to the Central Cooperative for Agricultural Research (COODETEC) for providing the dataset used in this study.

\section{References}

AACCI - American Association of Cereal Chemists International (2010) Approved Methods of Analysis. 11th ed. AACC International.

Adom KK, Sorrells ME, Liu RH (2003) Phytochemical profiles and antioxidant activity of wheat varieties. Journal of Agricultural and Food Chemistry 51:7825$-7834$.

Bakker MM, Govers G, Ewert F, Rounsevell M, Jones $R$ (2005) Variability in regional wheat yields as a function of climate, soil and economic variables: assessing the risk of confounding. Agriculture, Ecosystems \& Environment 110(3):195-209.

Bilgin O, Guzmán C, Başer İ, Crossa J, Korkut KZ (2016) Evaluation of grain yield and quality traits of bread wheat genotypes cultivated in northwest turkey. Crop Science 56:73-84.

Cruz CD (2013) GENES: software para análise de dados em estatística experimental e em genética quantitativa. Acta Scientiarum. Agronomy 35(3):271$-276$.

del Pozo A, Matus I, Serret MD, Araus JL (2014) Agronomic and physiological traits associated with breeding advances of wheat under high-productive Mediterranean conditions. The case of Chile. Environmental and Experimental Botany 103:180-189.

Guarienti EM, Ciacco CF, Cunha GR, Del Duca LJA, Camargo CMO (2003) Avaliação do efeito de variáveis meteorológicas na qualidade industrial e no rendimento de grãos de trigo pelo emprego de análise de componentes principais. Ciência e Tecnologia de Alimentos 23:500-510.

Hung PV, Hatcher DW (2011) Ultra-performance liquid chromatography (UPLC) quantification of carotenoids in durum wheat: Influence of genotype and environment in relation to the color of yellow alkaline noodles (YAN). Food Chemistry 25:1510-1516.

Li Y, Wu Y, Hernandez-Espinosa N, Peña RJ (2013) The influence of drought and heat stress on the expression of end-use quality parameters of common wheat. Journal of Cereal Science 57(1):73-78.
Lukow OM, Adams K, Suchy J, Depauw RM, Humphreys G (2013) The effect of the environment on the grain colour and quality of commercially grown Canada hard white spring wheat, Triticum aestivum $\mathrm{L}$. 'Snowbird'. Canadian Journal of Plant Science 93:1-11.

Mohammed A, Geremew B, Amsalu A (2012) Variation and associations of quality parameters in ethiopian durum wheat (Triticum turgidum L. var. durum) genotypes. International Journal of Plant Breeding and Genetics 6:17-31.

Peña E, Bernardo A, Soler C, Jouve N (2005) Relationship between common wheat (Triticum aestivum L.) gluten proteins and dough rheological properties. Euphytica 143:169-177.

RCBPTT - Reunião da Comissão Brasileira de Pesquisa de Trigo e Triticale, 2., 2008, Passo Fundo. Informações técnicas para a safra 2009: trigo e triticale. Passo Fundo: Comissão Brasileira de Pesquisa de Trigo e Triticale: Embrapa Trigo: Embrapa Transferência de Tecnologia, 172p.

Silva RR, Benin G, Marchese JA, Silva ÉDB, Marchioro VS (2014) The use of photothermal quotient and frost risk to identify suitable sowing dates for wheat. Acta Scientiarum. Agronomy 36:99-110.

Souza EJ, Martin JM, Guttieri MJ, O'brien KM, Habernicht DK, Lanning SP, Mclean R, Carlson GR, Talbert LE (2004) Influence of genotype, environment, and nitrogen management on spring wheat quality. Crop Science 44:425-432.

Surma M, Adamski T, Banaszak Z, Kaczmarek Z, Kuczynska A, Majcher M, Ługowska B, Obuchowski W, Salmanowicz B, Krystkowiak K (2012) Effect of genotype, environment and their interaction on quality parameters of wheat breeding lines of diverse grain hardness. Plant Production Science 15: 192-203.

Taghouti M, Gaboun F, Nsarellah N, Rhrib R, El-Haila M, Kamar M, Abbad-Andaloussi F, Udupa SM (2010) Genotype x Environment interaction for quality traits in durum wheat cultivars adapted to different environments. African Journal of Biotechnology 9:3054-3062.

Tayyar S (2010) Variation in grain yield and quality of Romanian bread wheat varieties compared to local varieties in northwestern Turkey. Romanian Biotechnological Letters 15:5189-5196.

Zanetti S, Winzeler M, Feuillet C, Keller B, Messmer M (2001) Genetic analysis of bread-making quality in wheat and spelt. Plant Breeding 120:13-19. 